\title{
Feasibility of Using Palmyrah Strips as Reinforcing Material in Cost Effective Houses
}

\author{
K. Baskaran, H. E. Mallikarachchi, M. J. P. L. M. Jayasekara, and G. A. T. Madushanka \\ Department of Civil Engineering, University of Moratuwa, Moratuwa, Sri Lanka
}

Correspondence should be addressed to H. E. Mallikarachchi; mhansini@rocketmail.com

Received 17 December 2013; Revised 15 March 2014; Accepted 15 March 2014; Published 14 April 2014

Academic Editor: F. Pacheco-Torgal

Copyright (C) 2014 K. Baskaran et al. This is an open access article distributed under the Creative Commons Attribution License, which permits unrestricted use, distribution, and reproduction in any medium, provided the original work is properly cited.

Construction of cost effective houses is a dilemma among the impoverished population in developing countries. The ever increasing price of traditional building materials results in high capital investments for residential buildings. Palmyrah is a significant economic resource, widely spread all over the northeast region of Sri Lanka. This research explores the technical feasibility of using heartwood of Palmyrah as a reinforcing member in lightly loaded concrete elements. Initially, mechanical properties of Palmyrah were examined through static bending, tensile, and compressive tests. Percentages of water absorption, dimensional stability, and anchorage bond strength were investigated to envisage the suitability of Palmyrah as reinforcement. Next, several short span slabs and beams reinforced with Palmyrah strips were subjected to tests. It was observed that Palmyrah reinforcement enhanced the moment capacity of the slabs and beams compared to unreinforced sections. Experimental failure loads of slabs and beams were higher than theoretically predicted values with Palmyrah reinforcement. Further, Palmyrah reinforced beams and slabs underwent flexural failures. Thus, it is concluded that heartwood of Palmyrah has the potential to be used as reinforcement in lightly loaded slabs and beams. Further research is recommended to investigate the durability and serviceability issues.

\section{Introduction}

The current energy crisis, provoked by indiscriminate industrial development and population growth, has caused increasing concerns about managing the limited energy resources available today. The pursuit of sustainable development, while providing shelter for the ever increasing world population without causing environmental degradation, has become a huge challenge.

Construction of cost effective houses is an ever-present problem all over the world. The recent escalation of steel prices has created controversial economic problems in developing countries like Sri Lanka, where steel is imported. In addition, after 2004 Indian Ocean tsunami and thirty years of internal conflict, the demand for cost effective houses has increased drastically in Sri Lanka. Lack of reliable technical information about local materials makes the consumers mainly depend on expensive industrialised materials for which the details are freely available.
In this context, there is an intense ongoing search for nonpolluting materials and manufacturing processes, which require less energy. Emphasis is placed on innovative, nonconventional materials and construction technologies. As a result, the concept of timber reinforcement has recently emerged in the construction field.

Timber is one of the sustainable building materials on earth, which is naturally renewable and recyclable and leaves a lighter footprint than any other. In its production, the embodied energy in wood is a fraction of the energy required to produce almost any other building material. There is ample evidence to prove that our ancestors have used timber strips to enhance the tensile strength of clay in daub houses.

The Palmyrah tree flourishes in tropical and subtropical climates in South East Asia. It is a cheap and replenishable agricultural resource, which is abundantly available in the dry zone of Sri Lanka. It is used in many structural applications such as purlins and rafters of residential dwellings. Although there is a great deal of local field experience with Palmyrah 
as a structural member, its feasibility to be substituted as reinforcement has not been searched yet.

Thus, as a preliminary step, this investigation has explored the feasibility of using Palmyrah strips as reinforcement in lightly loaded and short span slabs and beams. Initially the suitability of using Palmyrah strips as a reinforcing material was examined through investigation of mechanical properties, water absorption, and bonding strength. The load bearing capacity of Palmyrah reinforced slabs and beams was experimented thereafter.

\section{Review of the Literature}

2.1. Timber Reinforcement. During the past few decades, there has been a growing interest in substituting bamboo and Babadua strips for steel reinforcement in concrete.

A series of research programmes have been conducted by Ghavami [1, 2], Ghavami and Hombeek [3], and Kankam et al. [4] to assess the suitability of bamboo reinforced light weight concrete elements for low stress applications. It is noteworthy to state that Ghavami has revealed that the tensile strength of bamboo is relatively high and can reach up to $370 \mathrm{MPa}$. This makes bamboo an attractive alternative to steel in tensile loading applications [3].

The results of investigations conducted by Ghavami demonstrated that, for the bamboo reinforced lightweight concrete beams, the ultimate applied load can be increased up to $400 \%$ as compared with the unreinforced concrete beams [2]. Moreover, further experiments concluded that 3\% of bamboo with respect to concrete section is the optimum recommended value of reinforcement [2].

According to Kankam, when bamboo reinforced two-way slabs have been subjected to concentrated central loading, experimental cracking loads were found to be on average $42 \%$ of the experimental ultimate loads and $15 \%$ greater than theoretical punching loads. Since punching failure always followed the full development of the flexural collapse mechanism, there is no fear of sudden shear failure [5].

Since the modulus of elasticity of bamboo is not as high as concrete, bamboo does not make a significant contribution to the flexural stiffness of bamboo reinforced concrete sections $[1,2]$. As discussed by Ghavami, other main shortcoming of bamboo is dimensional variation of bamboo strips within concrete due to moisture and temperature effects, which lead to cracking of concrete during service life $[1,2]$.

Laboratory tests were carried out by Kankam on one-way and two-way concrete slabs reinforced with Babadua bars. Experimental failure loads of one way slabs were found to be on average $300 \%$ and $175 \%$ of the theoretically predicted values for unreinforced section and Babadua reinforced section, respectively [6]. On average, monotonic and cyclic failure loads of two-way slabs were approximately 330\% and $270 \%$ greater than the theoretical flexural strength of unreinforced concrete section, respectively. They were also $170 \%$ and $200 \%$ higher than the theoretical flexural strength including Babadua bars [5].

The above studies have depicted that strips of some ecological materials satisfy fundamental requirements to be used as reinforcing bars in concrete elements. After water repellent treatments, they have shown no decay in concrete medium. However, swelling and shrinkage of timber and low bonding strength between timber and concrete are still critical issues which limit their applications in composites.

\section{Methodology}

The experimental procedure comprised two main sections. Initially eligibility of Palmyrah as a reinforcing material was scrutinized by determining mechanical and physical properties of Palmyrah. Then Palmyrah reinforced concrete beams and slabs were cast and tested to find the ultimate carrying capacity.

3.1. Testing of Palmyrah Strips. Tests were conducted in compliance with BS 373:1957 to determine the mechanical properties of Palmyrah from various regions in the country [7]. Static bending test and compressive test were done using a Universal Timber Testing Machine whereas tensile test was performed by tensometer as demonstrated in Figures 1(a), 1(b), and 1(c).

Bending strength, modulus of elasticity, and tensile and compressive strength parallel to grain were determined and the characteristic values have been derived by statistical analysis. Characteristic values were taken as lower fifth percentile value of the distribution.

3.2. Water Absorption Test. Eight samples were subjected to water absorption test, of which four were coated with varnish. They were immersed in water after measuring their initial weights. Weights of water absorbed samples were measured with time. Dimensions of all the samples were measured prior to the test and after 24 hours of water absorption. Then, they were oven-dried for 24 hours under normal atmospheric temperature and dimensions were taken again.

3.3. Pullout Test. Four treated and untreated Palmyrah strips of $10 \mathrm{~mm} \times 10 \mathrm{~mm}$ cross-section were used for the pullout test. In treated samples, varnish was applied to reduce water absorption and sand was pressed to increase the bond with concrete. $12 \mathrm{~cm}-14 \mathrm{~cm}$ length of strips was anchored in $150 \mathrm{~mm} \times 150 \mathrm{~mm} \times 150 \mathrm{~mm}$ concrete cubes. Verticality of Palmyrah strip had to be maintained in the process. After 28 days, pullout forces of each sample were measured in an Amsler Testing Machine. Anchorage bond strength was derived from (1). Consider

$$
\text { Bond Strength }=\frac{F}{L \times S} .
$$

\subsection{Testing Palmyrah Reinforced Slabs and Beams}

3.4.1. Preparing Samples. $1.2 \mathrm{~m}$ long Palmyrah strips which had two types of cross-sectional dimensions $(10 \mathrm{~mm} \times 10 \mathrm{~mm}$ and $20 \mathrm{~mm} \times 20 \mathrm{~mm}$ ) were cut and planed. All strips were painted with varnish, sand pressed, and dried for 24 hours as a water treatment. Grade 20 concrete was utilized for casting slabs and beams. 


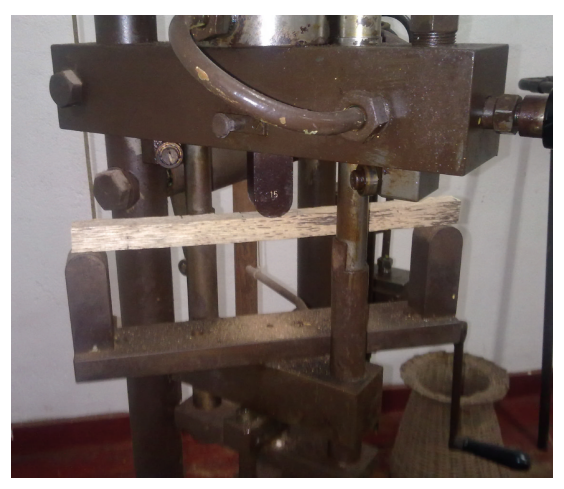

(a)

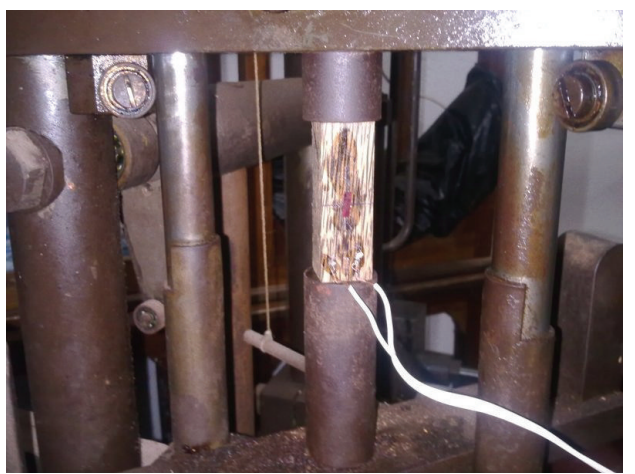

(b)

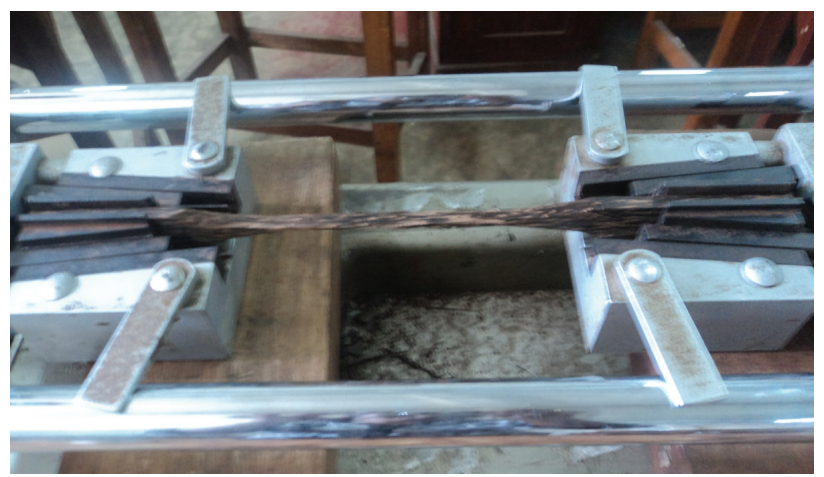

(c)

Figure 1: (a) Static bending test, (b) compressive test, and (c) tensile test.

Dimensions of the slab were $1200 \mathrm{~mm} \times 1200 \mathrm{~mm} \times$ $60 \mathrm{~mm}$ whereas dimensions of the beams were $1200 \mathrm{~mm} \times$ $150 \mathrm{~mm} \times 150 \mathrm{~mm}$. Reinforcement mesh of slabs was prepared with Palmyrah strips of $10 \mathrm{~mm} \times 10 \mathrm{~mm}$ in both longitudinal and transverse directions. Cover blocks of $15 \mathrm{~mm}$ thickness were tied to the net. Reinforcement details of slabs are given in Table 1, Figures 2(a) and 2(b).

In beams, Palmyrah strips were used as top and bottom longitudinal reinforcement and mild steel shear links were used at $80 \mathrm{~mm}$ spacing along the total beam length. Beam 1 was cast without any reinforcement for comparison purpose and other beams had increasing percentage of reinforcement. Arrangement of beam reinforcement is given in Table 2 and Figures 3(a) and 3(b).

3.4.2. Testing of Slabs and Beams. After 28 days from casting, the slabs and beams were coated with white lime. This process is essential, because it will give a better view of crack shapes and mode of failure during the test.

The slab was supported on two I beams with $50 \mathrm{~mm}$ bearing on either side. A dial gauge was arranged to measure the central deflection of the slab. After taking the initial dial gauge readings, line load was applied at the centre by means of a hydraulic jack placed on an I beam as shown in Figures 4(a) and 4(b). The test procedure included crack monitoring and central deflection measurements.

The beams were also simply supported with $50 \mathrm{~mm}$ bearing on either side. A dial gauge was arranged to measure
TABLE 1: Reinforcement details of slabs.

\begin{tabular}{lcccc}
\hline & $\begin{array}{c}\text { Cross-section of } \\
\text { Palmyrah strips } \\
\mathrm{mm} \times \mathrm{mm}\end{array}$ & $\begin{array}{c}\text { Spacing } \\
\mathrm{mm}\end{array}$ & $\begin{array}{c}\text { Reinforcement } \\
\text { percentage }\end{array}$ & $\begin{array}{c}\text { Cover } \\
\mathrm{mm}\end{array}$ \\
\hline Slab 1 & $10 \times 10$ & 300 & $0.7 \%$ & 15 \\
Slab 2 & $10 \times 10$ & 100 & $1.8 \%$ & 15 \\
\hline
\end{tabular}

the central deflection of the beam. After taking the initial dial gauge readings, two-point loading was applied as shown in Figures 5(a) and 5(b). Dial gauge readings were taken for each load increment. Failure loads as well as initial crack loads were observed for each beam.

\section{Results and Discussion}

4.1. Suitability of Palmyrah as a Reinforcing Material. The properties of Palmyrah determined from machine testing are summarised in Table 3. It is concluded that only the heartwood part of Palmyrah trunk in which tensile strength can reach up to $170 \mathrm{~N} / \mathrm{mm}^{2}$ is suitable for reinforcing [8].

The cumulative water absorption of Palmyrah strips with time is plotted in Figure 6. During the 50 hours of the test, Palmyrah absorbed water continuously, even if the absorption rate has been reduced with time. Water absorption of Palmyrah after 24 hours was lower than that of bamboo when compared with previously published results [1]. 


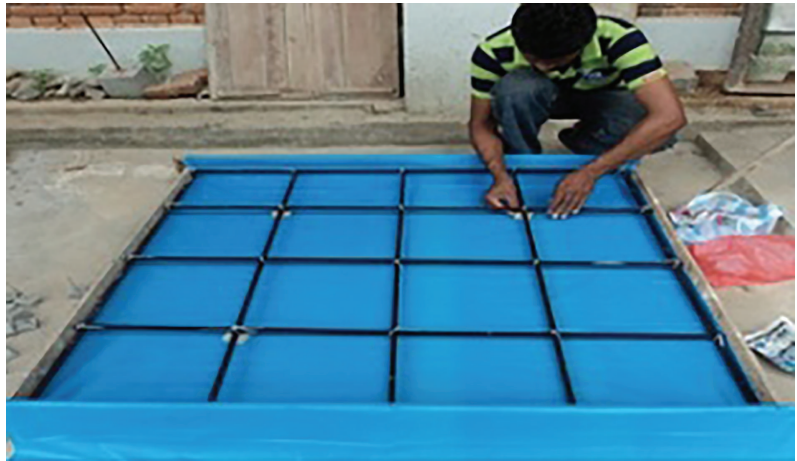

(a)

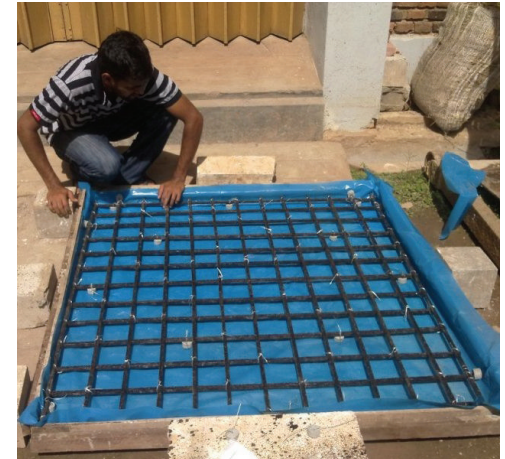

(b)

Figure 2: Bottom reinforcement of slabs, (a) $300 \mathrm{~mm}$ spacing and (b) $100 \mathrm{~mm}$ spacing.

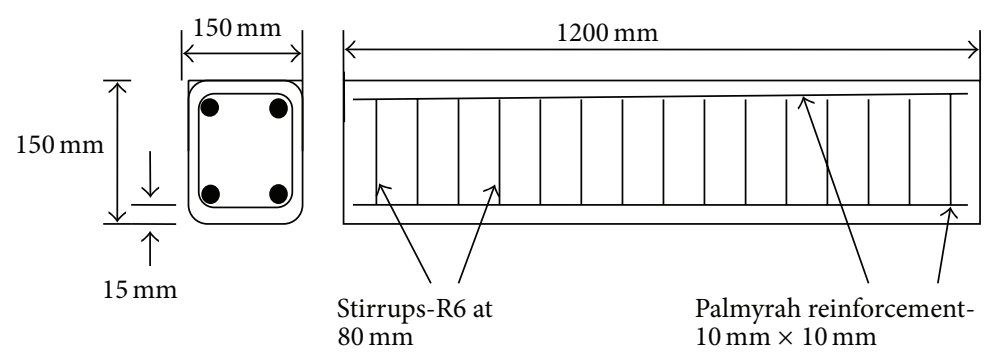

(a)

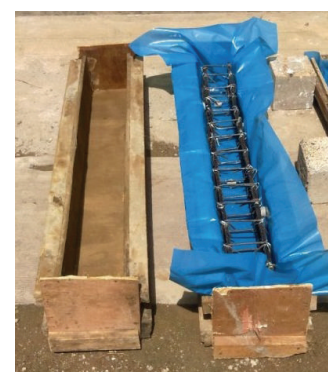

(b)

Figure 3: (a) and (b) Arrangement of beam reinforcement.

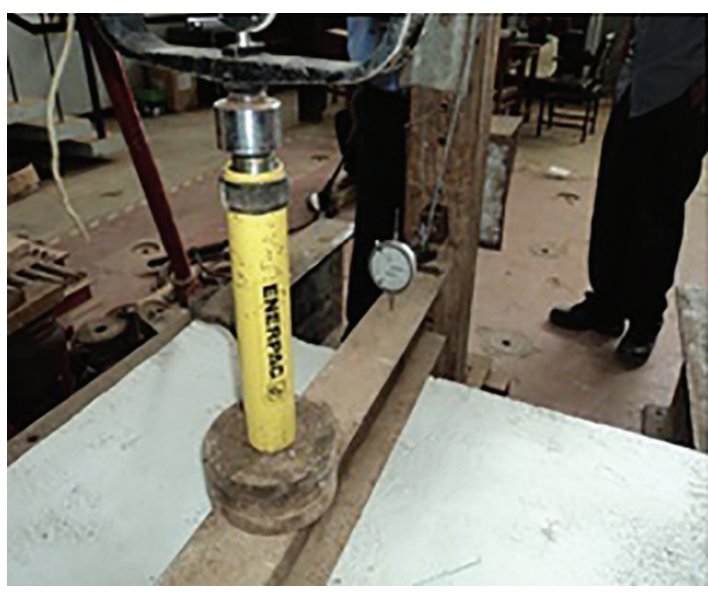

(a)

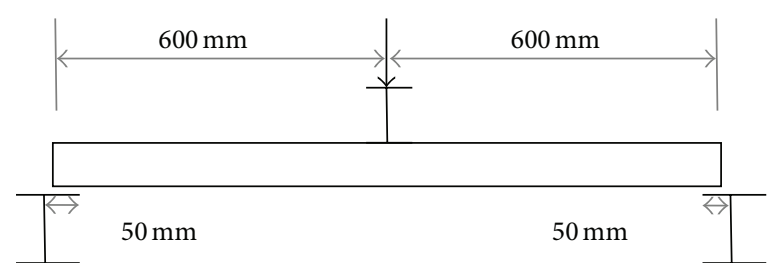

(b)

Figure 4: (a) and (b) Testing of slabs.

TABLE 2: Reinforcement details of beams.

\begin{tabular}{lccc}
\hline & $\begin{array}{c}\text { Area of bottom } \\
\text { reinforcement } \\
\text { number } \times \mathrm{mm} \times \mathrm{mm}\end{array}$ & $\begin{array}{c}\text { Area of top } \\
\text { reinforcement } \\
\text { number } \times \mathrm{mm} \times \mathrm{mm}\end{array}$ & $\begin{array}{c}\text { Reinforcement } \\
\text { percentage }\end{array}$ \\
\hline Beam 1 (without $\mathrm{r} / \mathrm{f})$ & $4 \times 10 \times 10$ & $2 \times 10 \times 10$ & $\begin{array}{c}\text { Cover } \\
\text { mm }\end{array}$ \\
Beam 2 & $6 \times 10 \times 10$ & $2 \times 10 \times 10$ & $3.67 \%$ \\
Beam 3 & $2 \times 20 \times 20$ & $2 \times 10 \times 10$ & $4.4 \%$ \\
Beam 4 & & & 15 \\
\hline
\end{tabular}




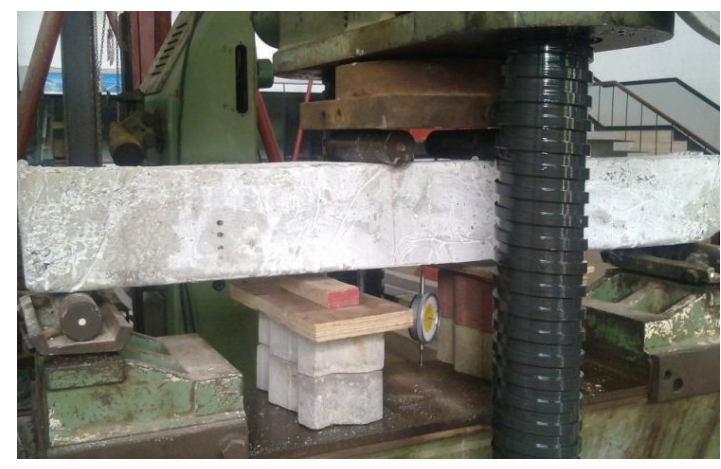

(a)

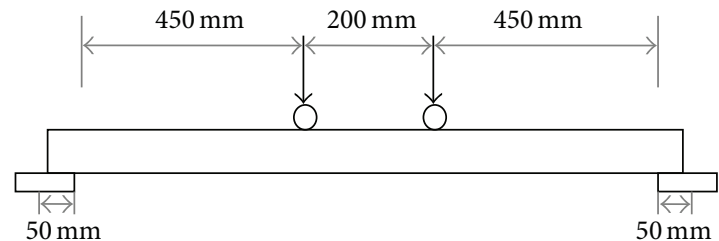

(b)

Figure 5: (a) and (b) Testing of beams.

TABLE 3: Mechanical properties of Palmyrah.

\begin{tabular}{|c|c|c|c|c|c|}
\hline \multicolumn{2}{|l|}{ Mechanical properties } & \multirow{2}{*}{$\begin{array}{c}\begin{array}{c}\text { Characteristic } \\
\text { value }\end{array} \\
80.3\end{array}$} & \multirow{2}{*}{$\begin{array}{c}\text { Minimum value } \\
48.9\end{array}$} & \multirow{2}{*}{$\begin{array}{c}\text { Average value } \\
138.3\end{array}$} & \multirow{2}{*}{$\begin{array}{c}\text { Standard deviation } \\
29.4\end{array}$} \\
\hline Bending strength $\left(\mathrm{N} / \mathrm{mm}^{2}\right)$ & $f_{m, k}$ & & & & \\
\hline $\begin{array}{l}\text { Modulus of elasticity } \\
\text { obtained from bending } \\
\text { test }\left(\mathrm{N} / \mathrm{mm}^{2}\right)\end{array}$ & $E_{\mathrm{bt}}$ & 9856.4 & 8787 & 13118.2 & 2622.4 \\
\hline $\begin{array}{l}\text { Tensile strength parallel to } \\
\text { grain }\left(\mathrm{N} / \mathrm{mm}^{2}\right)\end{array}$ & $f_{t, 0, k}$ & 44 & 43 & 87.7 & 41.8 \\
\hline $\begin{array}{l}\text { Compressive strength } \\
\text { parallel to grain }\left(\mathrm{N} / \mathrm{mm}^{2}\right)\end{array}$ & $f_{c, 0, k}$ & 51.8 & 37.1 & 72.7 & 14.8 \\
\hline Moisture content $\%$ & & 12.6 & 12 & 15 & 2.1 \\
\hline Density $\left(\mathrm{kg} / \mathrm{m}^{3}\right)$ & & 815.3 & 681 & 989.7 & 104.5 \\
\hline
\end{tabular}

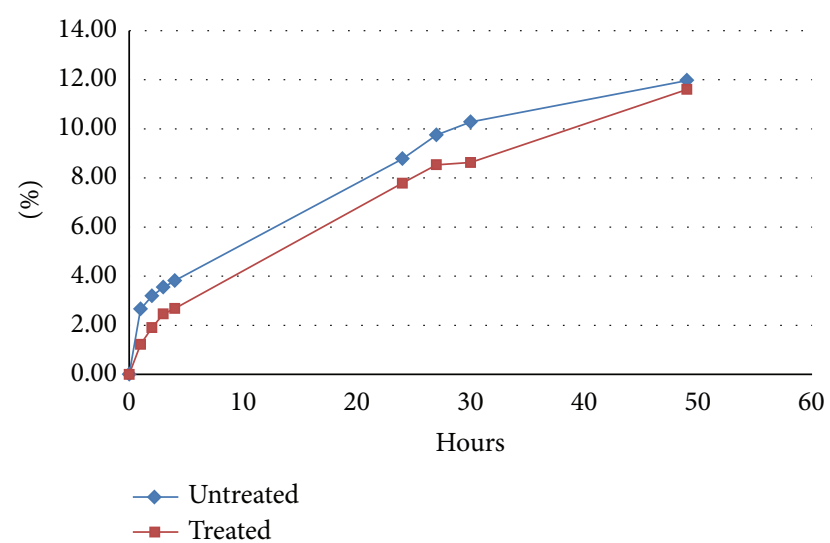

FIGURE 6: Cumulative water absorption of Palmyrah strips.

Also it is evident that applying varnish has reduced the water absorption initially. But its effectiveness diminished afterwards.

The volumetric stability incorporates both cross-sectional area and length changes, which are critical when Palmyrah is to be used as a reinforcing material embedded in concrete. During casting and curing, water will be absorbed by Palmyrah from concrete. When Palmyrah strips are embedded in concrete swells, it will generate cracks in concrete.
After sometime, it will shrink back leaving voids, so that the bond with concrete is reduced.

Average variations of lengths and cross-sections of Palmyrah samples after swelling by water absorption and shrinkage by subsequent drying are tabulated in Table 4 . The plus mark reflects increase in the dimensions and the minus mark shows decrease in dimensions from previous stage. Average bond strengths calculated from pullout test with standard deviation in brackets are summarized in Table 5.

Although Palmyrah is not fully dimensionally stable as steel, it has low variation in dimensions compared with other timber reinforcements [1]. Bond strength of Palmyrah is lower than that of bamboo obtained from similar pullout tests (with treatment: $1.55 \mathrm{~N} / \mathrm{mm}^{2}$, without treatment: $1.2 \mathrm{~N} / \mathrm{mm}^{2}$ ), when compared with values published previously by Ghavami [1].

4.2. Palmyrah Reinforced Slabs and Beams. The experimental failure loads and crack initiation loads of slabs and beams are tabulated in Table 6. The experimental, mean cube strengths were $21.5 \mathrm{~N} / \mathrm{mm}^{2}$ and $24.4 \mathrm{~N} / \mathrm{mm}^{2}$ for slabs and beams, respectively.

Table 6 depicts that experimental collapse loads of both slabs and beams have increased with reinforcement percentage. Both slabs exhibited flexural failures and collapse was due to fracture of Palmyrah reinforcement. Slab 1 failed in almost 
TABLE 4: Dimensional variations of Palmyrah.

\begin{tabular}{lcccc}
\hline \multirow{2}{*}{$\begin{array}{l}\text { Sample } \\
\end{array}$} & \multicolumn{2}{c}{ After 24hr water absorption } & \multicolumn{2}{c}{ After 24 hr drying } \\
& Cross-section & Length & Cross-section & Length \\
\hline Untreated set & +2.56 & +0.027 & -1.13 & 0 \\
Treated set & +2.4 & +0.013 & -1.1 & 0 \\
\hline
\end{tabular}

TABLE 5: Bond strength and anchorage lengths of Palmyrah.

\begin{tabular}{lcc}
\hline Sample & $\begin{array}{c}\text { Anchorage length } \\
(\mathrm{mm})\end{array}$ & $\begin{array}{c}\text { Bond strength } \\
\left(\mathrm{N} / \mathrm{mm}^{2}\right)\end{array}$ \\
\hline With treatment & $131(11)$ & $1.445(0.1)$ \\
Without treatment & $125(12.5)$ & $1.315(0.06)$ \\
\hline
\end{tabular}

TABLE 6: Experimental failure loads and crack initiation loads.

\begin{tabular}{lcccc}
\hline & $\begin{array}{c}\text { Percentage of } \\
\text { reinforcement }\end{array}$ & $\begin{array}{c}\text { Crack } \\
\text { initiation } \\
\text { load } P_{\text {cr }}(\mathrm{kN})\end{array}$ & $\begin{array}{c}\text { Experimental } \\
\text { failure load } \\
P_{e}(\mathrm{kN})\end{array}$ & $P_{\text {cr }} / P_{e}$ \\
\hline Slab 1 & $0.7 \%$ & & 6.64 & \\
Slab 2 & $1.8 \%$ & 10.4 & 16.48 & 0.63 \\
Beam 1 & $0 \%$ & & 8.83 & \\
Beam 2 & $2.67 \%$ & 7.45 & 24.13 & 0.31 \\
Beam 3 & $3.5 \%$ & 8.83 & 24.72 & 0.36 \\
Beam 4 & $4.4 \%$ & 9.81 & 30.02 & 0.33 \\
\hline
\end{tabular}

brittle manner with little warning so that crack initiation load was indistinguishable. But, with increase in an amount of reinforcement from $0.7 \%$ to $1.8 \%$, collapse of the slab became remarkably gradual.

Collapse of beams with Palmyrah reinforcement (Beams 2,3 , and 4) was gradual while collapse of the unreinforced beam was so sudden. Difference between crack load and failure loads was indistinguishable in Beam 1 . The unreinforced beam had a diagonal shear failure at one of the loading points whereas other beams experienced flexural failures. Failure modes and crack propagation of both slabs and beams are shown in Figures 7(a) and 7(b), respectively. It is evident that crack load of beams averages to one third of failure load.

Load deflection curves of the two slabs and the four beams are plotted in Figures 8(a) and 8(b), respectively.

The gradients of the load deflection curve of test slabs were relatively high until the appearance of the first crack in the central region of the bottom of the slab. Immediately following this first crack, there was a noticeable flattening of the deflection curve as the line of crack at the bottom widened. Large deflection without warning is due to low value of modulus of elasticity of Palmyrah.

In a beam subjected to two-point loading, the central region between two loads undergoes maximum bending moment and zero shear while the remaining sections experience maximum shear force and varying bending moment. The largest flexural strains, therefore, occur within this middle span and consequently cracking is initiated at the bottom of this region. All the cracks formed within the short constant moment span of approximately $200 \mathrm{~mm}$, and this implies that the beams have developed adequate resistance against diagonal shear. Also, Beams 2, 3, and 4 developed multiple cracks indicating good bond between the reinforcing Palmyrah bars and surrounding concrete. Figure 8(b) shows that, up to the appearance of the first tension crack in the central zone, all the beams showed the same rigidity and a linear behaviour. After that, there was a noticeable increase of deflection in Beams 2, 3, and 4 . Beam 1 which was without reinforcement showed the highest stiffness.

4.3. Moment Capacity of Slabs and Beams. Based on the failure loads in Table 6, experimental moment capacities of slabs and beams were calculated. For the determination of theoretical moment capacity, experimental properties of concrete derived from cube strength, minimum tensile strength, and elastic modulus of Palmyrah reinforcement bars determined from mechanical testing were used. Tensile strength of concrete was derived from equations in BS 8110, 1997 , using cube strength. The theoretical moment capacity of unreinforced section was derived from (2), as given below;

theoretical moment capacity of unreinforced section:

$$
\mathrm{Mt}_{c}=\frac{f_{c t} \times b \times h^{2}}{6} .
$$

The theoretical moment capacity considering the contribution of Palmyrah reinforcement was calculated by trial and error process using fundamental concepts such as strain compatibility, force equilibrium, and moment equilibrium.

The stress strain diagrams in Figure 9 were assumed at the failure for calculation purposes. Since both slabs and beams collapsed by fracture of Palmyrah bars, strain of Palmyrah is assumed to reach its breaking strain before concrete reached its ultimate strain.

Table 7 depicts that Palmyrah reinforcement has enhanced the moment capacity of Slab 1 by $23 \%$ and Slab 2 by $193 \%$ compared with an unreinforced slab. Experimental moment capacities are $7.4 \%$ and $71 \%$ higher than theoretically predicted value with Palmyrah reinforcement for Slabs 1 and 2 , respectively. The reason for this difference may be that the theoretical value is based on minimum tensile strength of Palmyrah.

The actual moment capacities of Beams 2, 3, and 4 are upgraded by $328 \%, 345 \%$, and $440 \%$ using Palmyrah reinforcement, compared with theoretically unreinforced beams. Experimental moment capacities of Beams 2, 3, and 4 are 


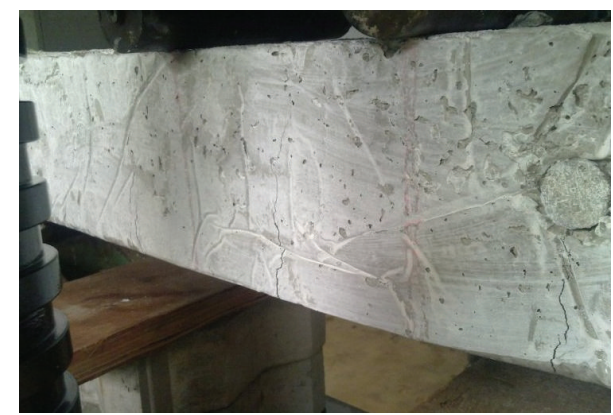

(a)

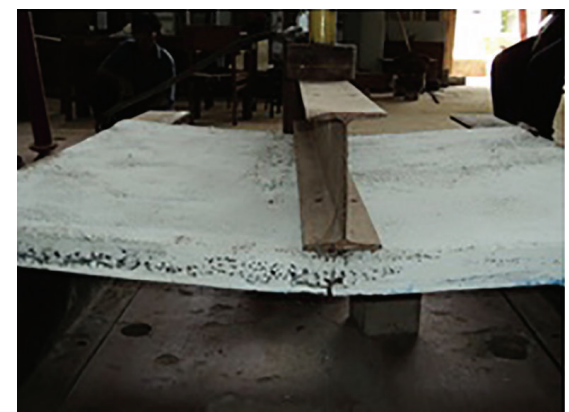

(b)

FIGURE 7: Crack propagation in (a) a beam and (b) a slab.

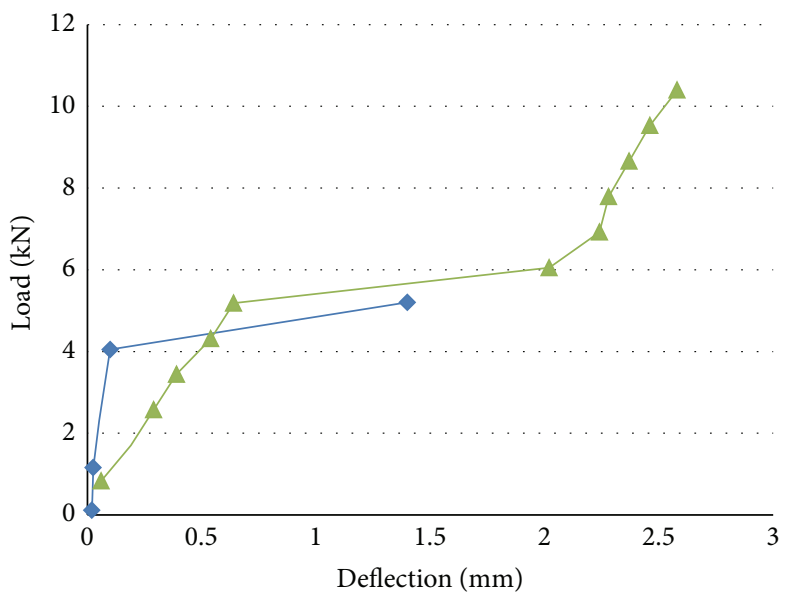

$\checkmark$ Slab 1

$\rightarrow$ Slab 2

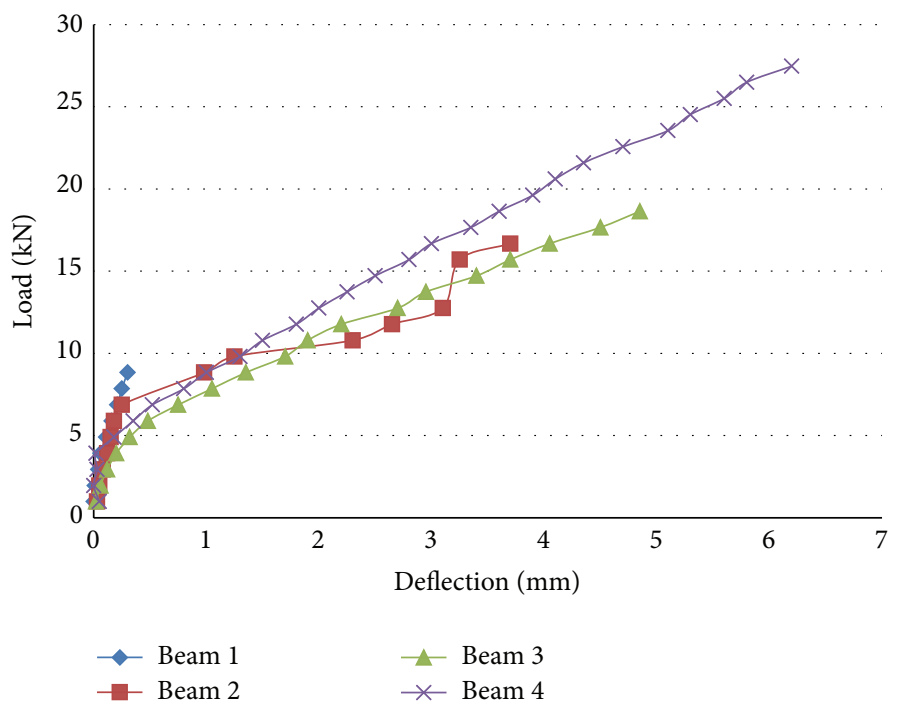

(b)

Figure 8: Load deflection curves of (a) slabs and (b) beams.

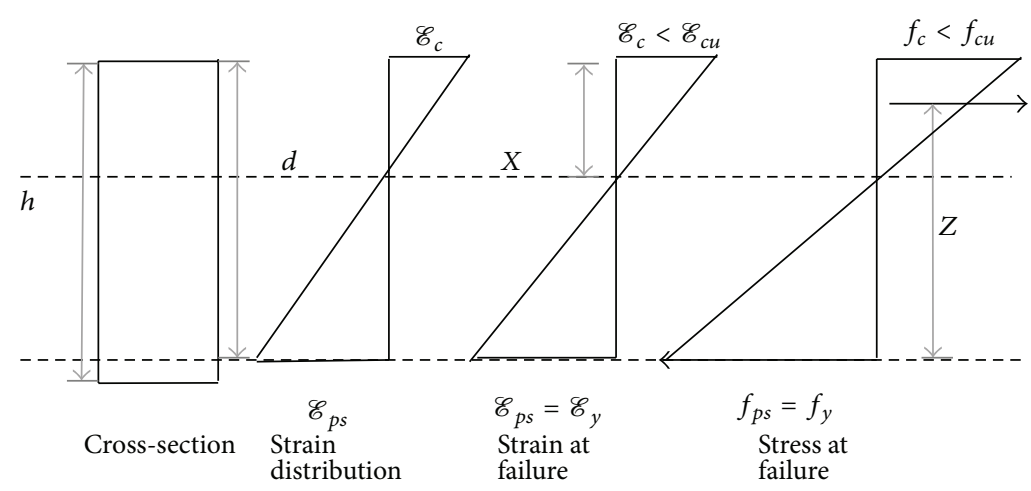

FIGURE 9: Stress and strain distribution of composite slabs and beams. 
TABLE 7: Calculated moment capacities of slabs and beams.

\begin{tabular}{|c|c|c|c|c|c|}
\hline & \multirow{2}{*}{$\begin{array}{c}\text { Experimental } \\
\text { moment capacity } \\
(\mathrm{kNm}) \\
\mathrm{Me} \\
\end{array}$} & \multicolumn{2}{|c|}{$\begin{array}{c}\text { Theoretical moment capacity }(\mathrm{kNm}) \\
\text { Mt }\end{array}$} & \multirow[b]{2}{*}{$\mathrm{Me} / \mathrm{Mt}_{c}$} & \multirow[b]{2}{*}{$\mathrm{Me} / \mathrm{Mt}_{p}$} \\
\hline & & $\begin{array}{l}\text { Based on concrete } \\
\text { section alone } \mathrm{Mt}_{c}\end{array}$ & $\begin{array}{l}\text { Including Palmyrah bars } \\
\text { in tension } \mathrm{Mt}_{p}\end{array}$ & & \\
\hline Slab 1 & 1.826 & 1.49 & 1.7 & 1.225 & 1.074 \\
\hline Slab 2 & 4.53 & 1.546 & 2.65 & 2.93 & 1.709 \\
\hline Beam 1 & 2 & 1.3 & - & & \\
\hline Beam 2 & 5.43 & 1.27 & 2.58 & 4.275 & 2.1 \\
\hline Beam 3 & 5.56 & 1.25 & 3.79 & 4.448 & 1.467 \\
\hline Beam 4 & 6.75 & 1.25 & 5 & 5.4 & 1.35 \\
\hline
\end{tabular}

$110 \%, 47 \%$, and $35 \%$ higher than theoretically predicted values with Palmyrah reinforcement. Furthermore, experimental moment capacities of Palmyrah reinforced beams are substantially higher than moment capacity of the unreinforced beam (Beam 1).

Although Palmyrah has not fully satisfied the eligibility criteria of a prospective reinforcing element, such as durability and ductility, heartwood of Palmyrah has a potential to replace steel reinforcement with some remedial actions to minimize undesirable characteristics. Change in dimensions of cross-section and length by water absorption and subsequent drying should be decreased as possible. Therefore, a better water repellent method than varnish should be used for this purpose.

Increase of the percentage of Palmyrah reinforcement results in increase of moment capacities of both slabs and beams. Compared to steel reinforced sections, these slabs and beams showed low stiffness in the postcracking region, due to low modulus of elasticity of Palmyrah.

Since crushing of concrete did not occur until reinforcement percentage of $4.4 \%$ from cross-section, it can be concluded that there is a higher margin for over reinforcement of Palmyrah, compared to steel.

Since slabs are short span, they are suggested to be used as precast slabs with secondary beams. Design calculations indicated that Palmyrah reinforced beams have sufficient moment capacity to be used as lintels of doors and windows of single storey or two-storey masonry walls. Therefore, when material safety factor of 3 is introduced for Palmyrah and safety factor of 1.5 is used for concrete, safe design can be achieved for floor slabs and lintel beams of residential buildings.

4.4. Economical and Environmental Feasibility. Palmyrah is abundantly available in Jaffna Peninsula, which is in the Northern part of Sri Lanka. Since Sri Lanka is a small island of 65,610 square kilometres, transport distance to working sites is limited. Price of $1 \mathrm{~m}$ of $2^{\prime \prime} \times 1^{\prime \prime}$ piece is Rs.165, including transport, sawing, splicing of bars, and water treatment. Maximum of 6 numbers of $10 \mathrm{~mm} \times 10 \mathrm{~mm}$ strips and 2 of $10 \mathrm{~mm} \times 10 \mathrm{~mm}$ strips can be cut from $2^{\prime \prime} \times 1^{\prime \prime}$ piece. Compared to steel, Palmyrah reinforcement can reduce the cost of $1.2 \mathrm{~m}^{2}$ panel nearly by $40 \%$ and cost of $1.2 \mathrm{~m}$ beam by $36 \%$. Heartwood ratio of a bottom part of a matured Palmyrah trunk is about $1 / 3$, which varies with origin of the tree. However, it is an eternal truth that there are repercussions of cutting down trees. If continuous plantation programmes are implemented to replenish logged trees, probable environmental impacts can be minimized.

\section{Conclusions and Recommendations for Future Studies}

The following conclusions were drawn from the conducted research.

(i) $10 \mathrm{~mm}$ square Palmyrah bars with anchorage length of $12-14 \mathrm{~cm}$ had bond strength about $1.3-1.4 \mathrm{~N} / \mathrm{mm}^{2}$ in grade 20 concrete.

(ii) Introducing Palmyrah strips into unreinforced concrete elements enhanced their moment capacity.

(iii) With increase of amount of reinforcement, collapse load as well as moment capacities of beams and slabs has increased.

(iv) Collapse mechanisms of Palmyrah reinforced slabs and beams were flexural failures by fracture of Palmyrah bars.

(v) Poor volumetric stability under absorption of water and low modulus of elasticity are major drawbacks when Palmyrah is utilized as a reinforcing material.

It should be noted that the above conclusions are based on limited number of test specimens, and further specimens should be tested prior to extensive use of Palmyrah as an alternative to steel reinforcement. Moreover, durability of Palmyrah reinforcement on the long term has to be scrutinised in detail in future as they have not been discussed within this research. Better water repellent methods and surface treatments to reduce water absorption and increase bond have to be further investigated. In addition, serviceability criteria such as deflection and crack width should be probed in detail and more specimens should be tested varying section thickness and reinforcement percentage to determine minimum optimum reinforcement. 


\section{List of Notations}

$f_{m, k}$ : Bending strength of Palmyrah

$E_{b t}$ : Modulus of elasticity of Palmyrah

$f_{t, 0, k}$ : Tensile strength of Palmyrah parallel to grain

$f_{c t}$ : Tensile strength of concrete

$b$ : Width of slab or beam

$h$ : Depth of slab or beam

$d$ : $\quad$ Effective depth of slab or beam

F: $\quad$ Pull-out force

L: $\quad$ Anchorage length

$S: \quad$ Perimeter of Palmyrah bar

$P_{c r}: \quad$ Crack initiation load

$P_{e}: \quad$ Experimental failure load

Me: Experimental moment capacity

$\mathrm{Mt}_{c}$ : Theoretical moment capacity of unreinforced section

$\mathrm{Mt}_{p}$ : Theoretical moment capacity with Palmyrah reinforcement

$f_{p s}:$ Stress of Palmyrah

$f_{y}$ : Breaking stress of Palmyrah

$f_{c}$ : Stress of concrete

$f_{c u}$ : Ultimate stress of concrete

$\mathscr{E}_{p s}:$ Strain of Palmyrah

$\mathscr{E}_{y}:$ Breaking strain of Palmyrah

$\mathscr{E}_{c}:$ Strain of concrete

$\mathscr{E}_{c u}$ : Ultimate strain of concrete

$X: \quad$ Depth to neutral axis

$Z$ : Lever arm.

\section{Conflict of Interests}

The authors declare that there is no conflict of interests regarding the publication of this paper.

\section{Acknowledgments}

The authors would like to acknowledge the staff of Department of Civil Engineering in University of Moratuwa for their assistance in carrying out the testing. The authors are also grateful towards Mr. Ravindraraja and Mr. Sarangan who supported purchasing and delivery of Palmyrah.

\section{References}

[1] K. Ghavami, "Bamboo as reinforcement in structural concrete elements," Journal of Cement and Concrete Composites, vol. 27, no. 6, pp. 637-649, 2005.

[2] K. Ghavami, "Ultimate load behaviour of bamboo-reinforced lightweight concrete beams," Journal of Cement and Concrete Composites, vol. 17, no. 4, pp. 281-288, 1995.

[3] K. Ghavami and R. V. Hombeeck, "Application of bamboo as a construction material. Part I: mechanical properties and water repellent treatment of bamboo. Part II: bamboo reinforced concrete beams," in Proceedings of the Latin American Symposium on Rational Organization of Building Applied to Low Cost Housing, pp. 49-66, CIB, Sao Paulo, Brazil, October 1981.
[4] J. A. Kankam, M. Ben-George, and S. H. Perry, "Bambooreinforced concrete two-way slabs subjected to concentrated loading," The Structural Engineer B: R\&D Quarterly, vol. 64, no. 4, pp. 85-92, 1986.

[5] C. K. Kankam and B. Odum-Ewuakye, "Babadua reinforced concrete two-way slabs subjected to concentrated loading," Construction and Building Materials, vol. 20, no. 5, pp. 279-285, 2006.

[6] C. K. Kankam and B. Odum-Ewuakye, "Flexural behaviour of babadua reinforced one-way slabs subjected to third-point loading," Construction and Building Materials, vol. 15, no. 1, pp. 27-33, 2001.

[7] British Standard Institute, "Method of testing small clear specimens of timber," Tech. Rep. BS 373, BSI, London, UK, 1957.

[8] H. E. Mallikarachchi, K. Baskaran, M. J. P. L. M. Jayasekara, and G. A. T. Madushanka, "A study on palmyrah as a material of construction," in Proceedings of the 2nd Annual Sessions of Society of Structural Engineers-Sri Lanka, vol. 2, pp. 7-16, September 2012. 

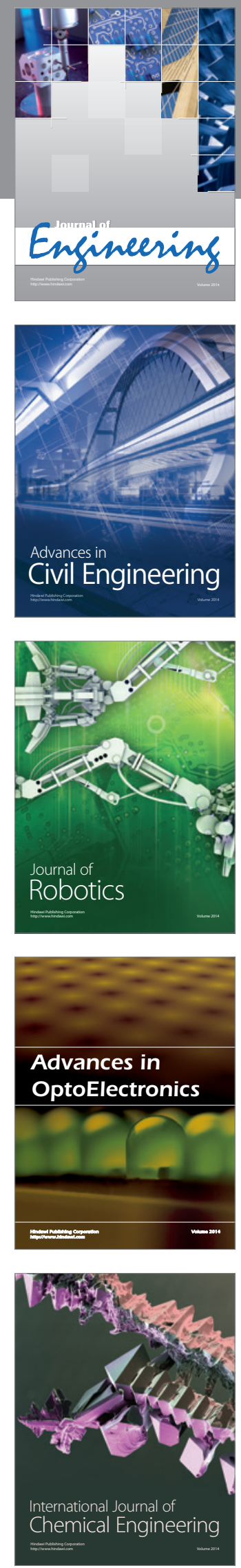

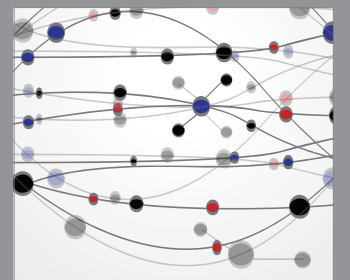

The Scientific World Journal
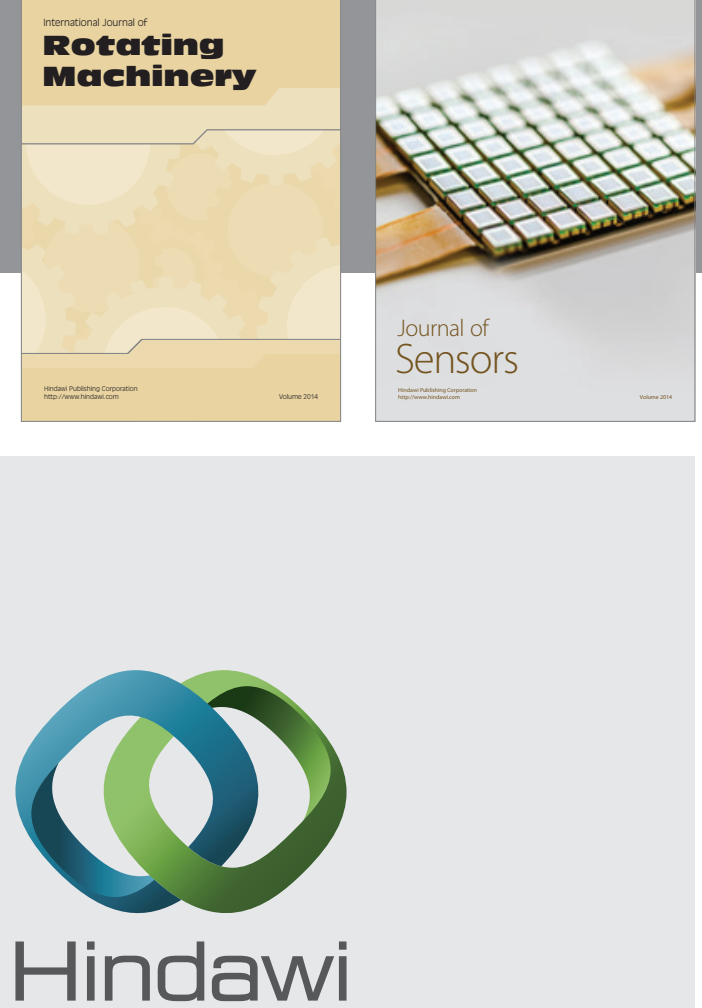

Submit your manuscripts at http://www.hindawi.com
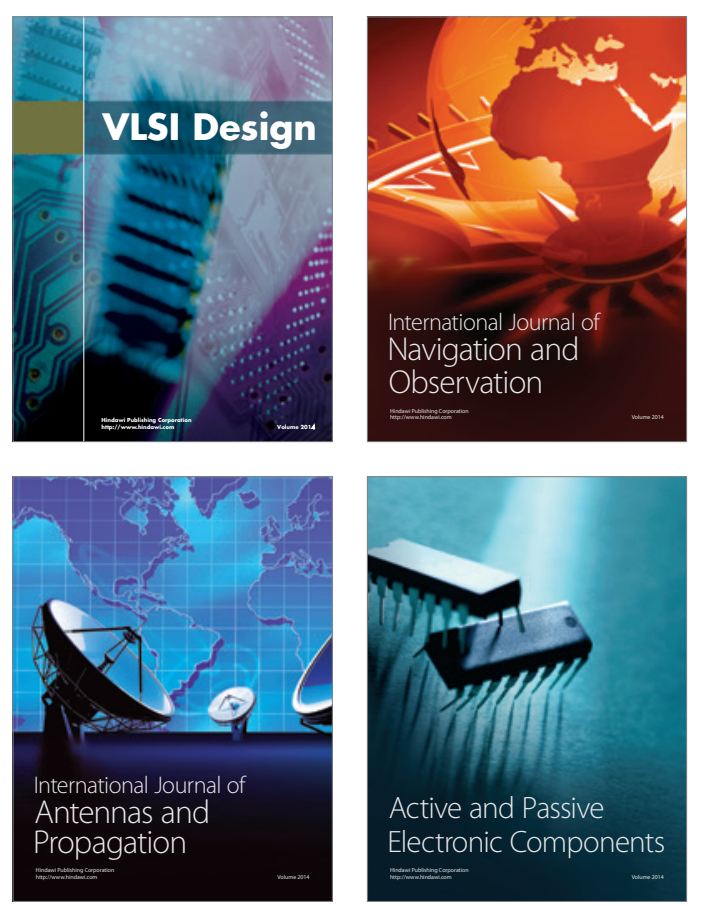
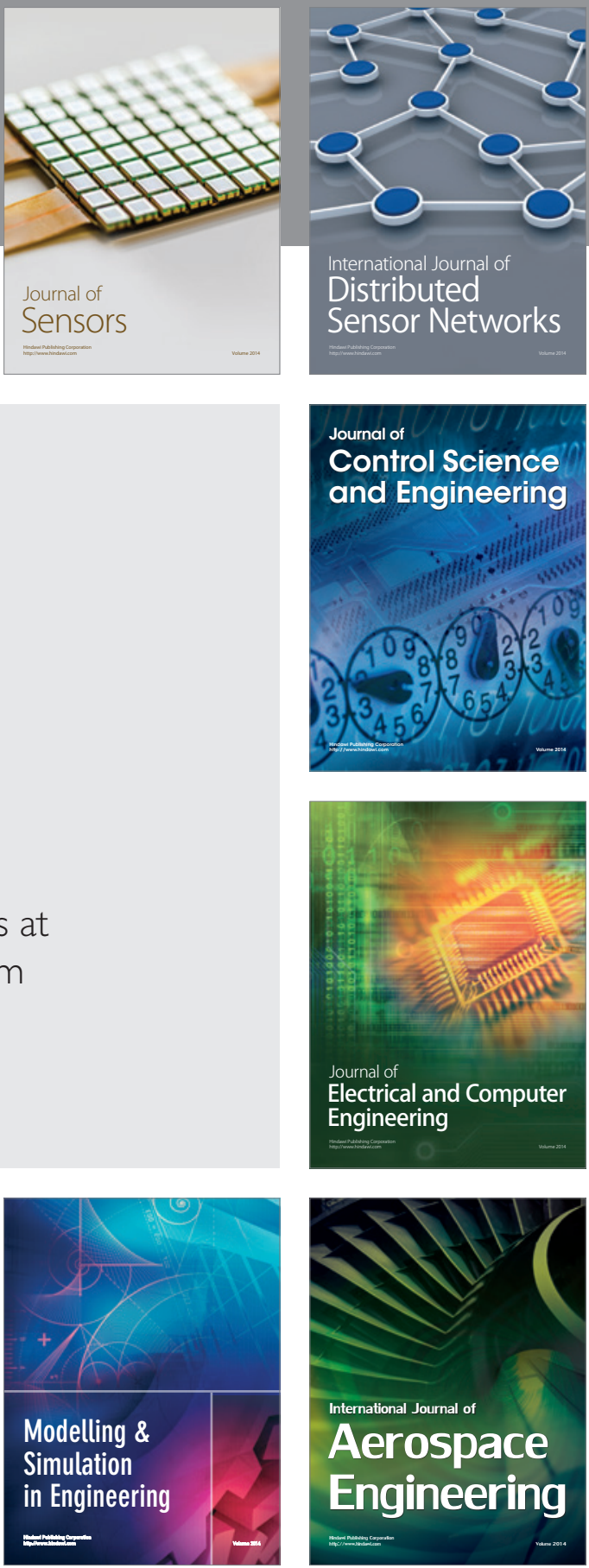

Journal of

Control Science

and Engineering
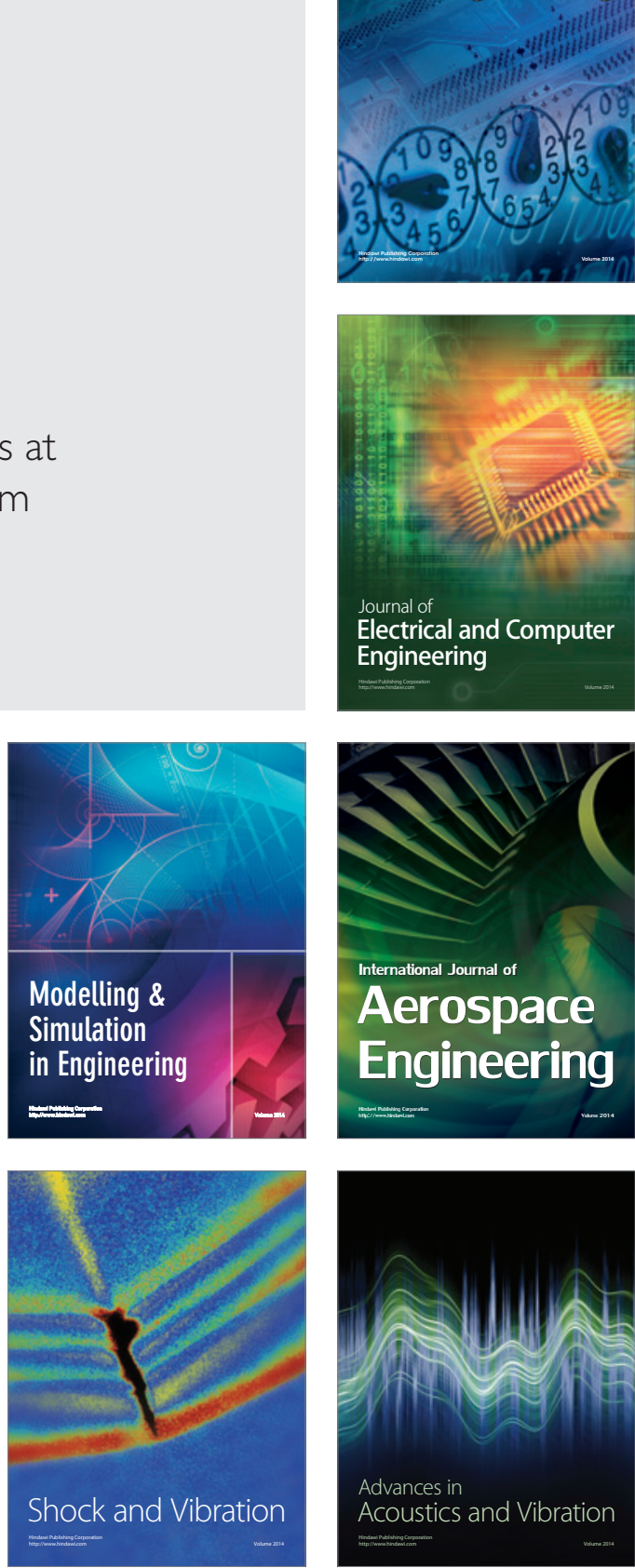